\title{
PENGARUH BRAND LEADERSHIP DAN PERCEIVED QUALITY TERHADAP CUSTOMER LOYALTY DENGAN BRAND PERSONALITY SEBAGAI VARIABEL PERANTARA DAN BRAND TRUST SEBAGAI VARIABEL INTERVENING PADA MERLION SCHOOL SURABAYA
}

\author{
Dave Natakusuma Imam Raharjo ${ }^{1, a, *}$; Diah Dharmayanti, ${ }^{1, b)}$ \\ ${ }^{1}$ Program Studi Manajemen Pemasaran, Universitas Kristen Petra \\ Jl. Siwalankerto 121-131, Surabaya 60236 \\ E-mail: ${ }^{\text {a) } 36411081 @ j o h n . p e t r a . a c . i d ;}{ }^{\text {b) }}$ diah_dharmayanti@yahoo.com \\ * Korespondensi
}

\begin{abstract}
Abstrak: Semakin pesatnya pertumbuhan industri di bidang pendidikan yang berupa banyak bermunculannya lembagalembaga pendidikan dengan berbagai kualitas menyebabkan semakin beragamnya pilihan konsumen dalam memilih lembaga/institusi pendidikan. Setiap lembaga/institusi berlomba-lomba untuk merebut hati konsumen sebagai upaya untuk mempertahankan eksistensinya di tengah pesatnya persaingan. Namun, untuk tetap bertahan di tengah persaingan bisnis ini, keunggulan kualitas hanyalah satu dari sekian banyak faktor yang mempengaruhi berkembang tidaknya suatu perusahaan. Oleh karena itu perlu diadakannya sebuah penelitian mengenai pengaruh brand leadership dan perceived quality terhadap customer loyalty melalui brand personality sebagai variable perantara dan brand trust sebagai variable Intervening pada merlion school Surabaya. Penelitian ini akan dilaksanakan dengan menyebarkan kuesioner kepada 100 responden konsumen Merlion School Surabaya. Hasil dari 100 responden menyatakan bahwa customer loyalty dari merlion school sangat di pengaruhi oleh Brand Personality yang di intervening dengan Brand Trust dan seluruh variable lainnya berpengaruh secara signifikan.
\end{abstract}

Kata kunci: Brand Leadership, Perceived Quality, Brand Personalities, Brand Trust, Customer Loyalty.

\begin{abstract}
The rapid growth of industries in the field of education which is the emergence of many educational institutions with a range of quality led to increasingly diverse consumer choice in selecting institution / educational institutions. Each institution/agency vying to win over consumers in an effort to maintain its presence in the midst of rapid competition. However, to remain competitive in this business, quality excellence is just one of many factors influencing the growing failure of a company. Therefore require the holding of a study on the effect of brand leadership and perceived quality on customer loyalty through brand personality as an intermediary variable and brand trust as an intervening variable in school Merlion Surabaya. This study will be conducted by distributing questionnaires to 100 respondents consumers Merlion School Surabaya. Results of the 100 respondents said that customer loyalty from Merlion school is influenced by Brand Personality who in intervening with the Brand Trust and all other variables influence significantly.
\end{abstract}

Keywords: Brand Leadership, Perceived Quality, Brand Personalities, Brand Trust, Customer Loyalty

\section{PENDAHULUAN}

Semakin pesatnya pertumbuhan industri di bidang pendidikan yang berupa banyak bermunculannya lembaga-lembaga pendidikan dengan berbagai kualitas menyebabkan semakin beragamnya pilihan konsumen dalam memilih lembaga/institusi pendidikan. Setiap lembaga/institusi berlomba-lomba untuk merebut hati konsumen sebagai upaya untuk mempertahankan eksistensinya di tengah pesatnya persaingan. Berbagai upaya dilakukan kperusahaan untuk terus mendapatkan konsumen baru serta mempertahankan konsumen lama. Upaya-upaya yang ditempuh setiap lembaga pendidikan tentu berbeda.
Salah satu upaya untuk merebut hati konsumen adalah dengan memprioritaskan dan mengutamakan konsumen melalui customer loyalty (kesetiaan pelanggan).

Penelitian ini akan dilakuakan di kota Surabaya. Sebagai kota pendidikan, Surabaya telah menyediakan sarana dan prasarana pendidikan yang memadai, meliputi tingkat pendidikan dasar, menengah dan pendidikan tinggi. Pengembangan kota Surabaya sebagai kota pendidikan bertujuan untuk pengembangan kualitas sumber daya manusia yang ada. Hingga saat ini, jumlah sekolah yang ada di Surabaya pada Tabel 1. 
Tabel 1. Jumlah sekolah dan siswa di Surabaya.

\begin{tabular}{lcccc}
\hline \multirow{2}{*}{$\begin{array}{c}\text { Tingkat } \\
\text { Pendidikan }\end{array}$} & \multicolumn{2}{c}{ Negeri (Pemerintah) } & \multicolumn{2}{c}{ Swasta } \\
\cline { 2 - 5 } & $\begin{array}{c}\text { Jumlah } \\
\text { Sekolah }\end{array}$ & $\begin{array}{c}\text { Jumlah } \\
\text { Siswa }\end{array}$ & $\begin{array}{c}\text { Jumlah } \\
\text { Sekolah }\end{array}$ & Jumlah \\
Siswa
\end{tabular}

Sumber: Informasi Data Pokok Kota Surabaya 2014

Berdasarkan pada Tabel 1 terlihat bahwa jumlah sekolah swasta lebih banyak dibanding dengan sekolah negeri. Selain itu jumlah siswa yang memilih untuk sekolah di sekolah swasta juga lebih besar dibanding dengan sekolah negeri.

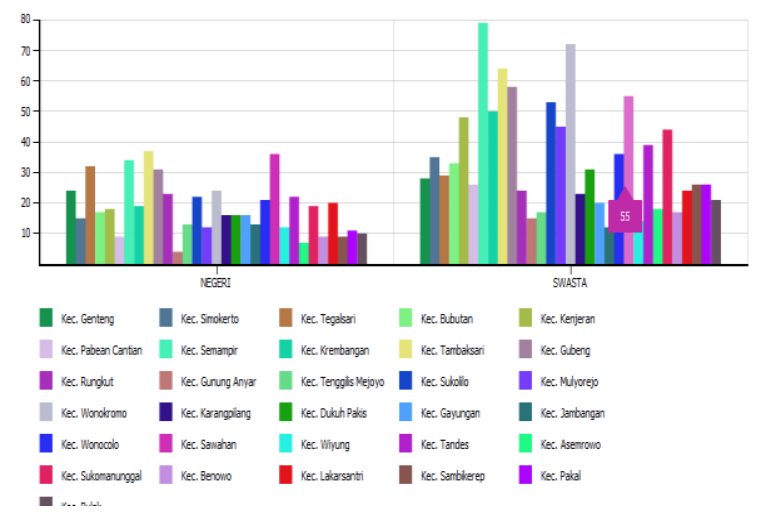

Gambar 1. Grafik Jumlah sekolah SD, SMP dan SMA/ SMK pada setiap kecamatan di Surabaya

Data perbedaan jumlah sekolah Negeri dan Swasta dapat terlihat pada gambar grafik 1. Grafik tersebut menjelaskan jumlah sekolah dari SD, SMP dan SMA/SMK di Surabaya yang didata berdasarkan setiap kecamatan. Data yang disajikan pada tabel 1.1 dan gambar grafik 1 menjelaskan bahwa pada dasarnya orang tua saat ini cenderung lebih tertarik untuk memilih sekolah swasta bagi anaknya ketimbang sekolah negeri. Hal ini menjelaskan juga bahwa orang tua memilih sekolah berdasarkan pada prestasi sekolah tersebut, baik itu akademik maupun non akademik.

Merlion School merupakan sekolah yang berbasis internasional dengan pilihan jenjang yang beragam mulai dari Taman Kanak-Kanak hingga Sekolah Menengah Atas (SMA). Kualitas yang ditawarkan Merlion School juga tidak sembarangan, lembaga pendidikan dengan basis internasional ini memiliki kualitas, proses pembelajaran dan pelayanan yang baik.

Merlion School memiliki keunggulan dibandingkan dengan pesaing-pesaing mereka, karena merlion school tidak hanya mengajarkan agar murid mereka pandai, tetapi juga memiliki karakter yang berkualitas. Memalui pendidikan etika, norma, dan perilaku yang masuk di dalam setiap kurikulum pendidikan yang ditanamkan dari nilai yang mereka bawa yaitu RICCH. RICCH adalah singkatan dari Responsibility, Integrity, Confident, Compation, Hard Working. Hal ini membentuk karakter dari Merlion dalam memajukan dan mendidik para siswanya. Namun, untuk tetap bertahan di tengah persaingan bisnis ini, keunggulan kualitas hanyalah satu dari sekian banyak faktor yang mempengaruhi berkembang tidaknya suatu perusahaan. Oleh karena itu perlu diadakannya sebuah penelitian mengenai pengaruh brand leadership dan perceived quality terhadap customer loyalty melalui brand personality sebagai variable perantara dan brand trust sebagai variable Intervening pada Merlion School Surabaya

\section{Rumusan Masalah}

Berdasarkan latar belakang permasalah, maka ditentukan permasalah yang diajukan adalah:

1. Apakah Brand Leadership berpengaruh terhadap brand personalities pada konsumen Merlion?

2. Apakah Brand Leadership berpengaruh terhadap brand trust pada konsumen Merlion?

3. Apakah perceived quality berpengaruh terhadap brand personalities di Merlion?

4. Apakah perceived quality berpengaruh terhadap brand trust di Merlion?

5. Apakah brand personalities berpengaruh terhadap brand trust pada konsumen Merlion?

6. Apakah brand trust berpengaruh terhadap customer loyalty di Merlion?

\section{TINJAUAN PUSTAKA}

\section{Brand Leadership}

Brand leadership juga dapat ditentukan dengan mempertimbangkan berbagai faktor situasional seperti sebagai faktor internal (yakni karakteristik produk) dan faktor eksternal (yakni industri dan kondisi pasar) (Chang dan Ko, 2013).

Pengaturan sistem adalah merk tradisional yang diganti menjadi pola pikir brand leadership karena memerlukan kesepakatan dengan kompleksitaskompetitif tekanan pasar baru seperti, perubahan saluran, kompetisi global, banyaknya merek, ekstensi merek agresif dan keluaran submerek yang kompleks. Pola pikir baru brand leadership berdasarkan pada asumsi sebelumnya: 
1. Membangun strategi merek harus selaras dengan strategi bisnis dari perusahaan bisnis secara keseluruhan

2. Pemimpin merek harus mempunyai strategi dan visi daripada terpusat pada taktik

3. Merek jangka panjang berwujud aset dari bisnis dan program yang membangun merek untuk terbentuknya aset yang mendukung bahwa kesuksesan masa depan dari perusahaan bisnis

4. Merek memungkinkan sebuah bisnis untuk menghindari keperluan kompetisi pada harga dan mempetahankan tingkat harga

5. Nilai nyata dari merek adalah kesulitan untuk mengukur ketepatnnya tetapi itu dapat menggunakan perkiraan persentase dari aliran pendapatan oleh setiap produk utama (Business News, 2013)

Menurut Chang dan Ko (2013) faktor-faktor yang mempengaruhi brand leadership adalah:

1. Perceived brand leadership

2. Perceived value

3. Perceived innovativeness

4. Perceived popularity

\section{Perceived Quality}

Perceived quality (presepsi kualitas) merupakan penilaian yang diberikan oleh konsumen atas suatu produk. Menurut Hellier et al (2003) perceived quality adalah penilaian konsumen secara keseluruhan terhadap proses standar produk yang diterima konsumen. Sedangkan menurut Aaker (1996) perceived quality adalah persepsi konsumen mengenai kualitas yang akan didapatkan oleh konsumen dari suatu produk baik barang maupun jasa.

David A. Garvin (1987) menyebutkan bahwa dimensi persepsi kualitas terbagi menjadi 7 (tujuh) yaitu:

1. Kinerja utama

2. Pelayanan pelayanan pada produk tersebut.

3. Ketahanan

4. Keandalan

5. Karakteristik produk

6. Kesesuaian dengan spesifikasi

7. Hasil

\section{Brand Personalities}

Menurut Durianto (2001:9-15) menyatakan bahwa Brand personalities adalah ikatan emosi merek dengan manfaat merek sebagai dasar diferensiasi merek. Brand personality menurut Kotler \&
Keller (2006:172), adalah sebagai berikut: Brand personality as the specific mix of human traits that may be attributed to a particular brand.

Menurut Kotler \& Amstrong (2004:140), brand personalities adalah suatu gabungan dari sifat manusia yang dapat diterapkan pada suatu merek.

1. Sincerity (ketulusan),

2. Excitement (semangat)

3. Competence (kemampuan

4. Sophistication (keduniawian

5. Ruggedness (ketangguhan),

\section{Brand Trust}

Menurut Lau dan Lee (1999: 344) brand trust didefinisikan sebagai keinginan pelanggan untuk bersandar pada sebuah merek dengan resiko-resiko yang dihadapi karena ekspektasi terhadap merek itu akan menyebabkan hasil yang positif dan Brand benefit.

Dimensi: Menurut Kustini (2011: 23), pengukuran brand trust dapat dilakukan melalui dimensi viabilitas (dimension of viability) dan dimensi intensionalitas (dimension of intentionality).
a. Fiability
b. Intentionality

\section{Customer Loyality}

Selanjutnya Griffin berpendapat bahwa seseorang pelanggan dikatakan setia atau loyal apabila pelanggan tersebut menunjukkan perilaku pembelian secara teratur atau terdapat suatu kondisi dimana mewajibkan pelanggan membeli paling sedikit dua kali dalam selang waktu tertentu. Bila seseorang merupakan pelanggan loyal maka akan menunjukkan perilaku pembelian dengan cara membeli secara tidak acak dari waktu ke waktu setelah pengambilan keputusan (Griffin, 2005).

Oliver (1999) menjelaskan 4 tahap dari loyalty yaitu terdiri dari cognitive loyalty, affective loyalty, conative loyalty, dan action loyalty. Berikut merupakan penjelasan lebih detail mengenai tahap-tahap tersebut:
a. Cognitive Loyalty
b. Affective Loyalty
c. Conative Loyalty.
d. Action Loyalty

\section{Kerangka Konseptual}

Kerangka konsep ini digunkaan untuk memberikan gambaran hubunga konsep penelitian ini. 


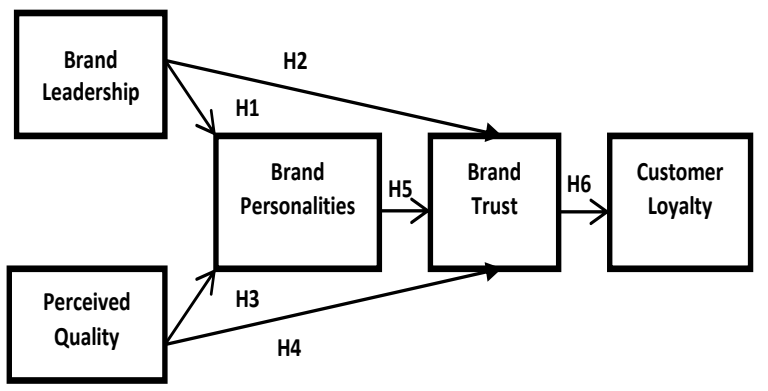

Gambar 2.

\section{METODE PENELITIAN}

\section{Gambaran Populasi dan Sampel}

Populasi dan Sampel

Teknik pengambilan sampel menggunakan non probability sampling, dan jenis yang digunakan adalah purposive sampling. Penentuan ukuran sampel adalah menentukan jumlah sampel yang digunakan dalam penelitian sedemikian rupa sehingga dapat mewakili populasinya. Dalam menentukan jumlah minimum sampel, penulis menggunakan rumusan Slovin, yaitu:

$n=\frac{\left(Z^{\frac{\alpha}{2}}\right)^{2} p(1-p)}{e^{2}}$

$n=\frac{(1,96)^{2} 0,5(1-0,5)}{0,10^{2}}$

$n=96,04 \rightarrow$ dibulatkan menjadi 100

Dimana:

$\mathrm{n} \quad=$ Jumlah sampel

$Z^{\frac{\alpha}{2}}=$ Angka yang menunjukkan suatu penyimpangan nilai variabel dari Mean dihitung dalam satuan deviasi standar tertentu $(1,96)$

$\mathrm{p}=$ Probabilitas $(0,5)$

$\mathrm{e}=$ Taraf kesalahan, disarankan $10 \%$

Jumlah sampel yang digunakan adalah 96,04 responden. Untuk memudahkan perhitungan maka jumlah responden dibulatkan menjadi 100 . Oleh karena itu, kuesioner akan disebarkan kepada 100 responden

\section{Definisi Operasional Variabel}

\section{Definisi Operasional Variabel}

Definisi operasional variable yang di gunakan dalam penelitian ini terdiri dari 5 variable, yaitu:

1. Variabel eksogen/indenpenden yaitu Brand leadership

\section{Brand Leadership (X1)}

Brand Leadership didefinisikan sebagai cara untuk melakukan perkembangan secara berbeda atau sifatnya trend-setter dengan tujuan yang berkonotasi positif serta dapat bersifat pembeda dengan kompetitor pada umumnya. Indikator dari Brand Leadership adalah:

1. Perceived Brand Leadership, yaitu kemampuan dari brand untuk dapat meyakinkan para konsumen tentang pembaharuan-pembaharuan yang bersifat trend-setter.

2. Perceived Value, yaitu persepsi dari konsumen yang memutuskan apakah harga sesuai dengan yang di dapatkan.

3. Perceived Innovativeness, adalah kemampuan dari brand yang di harapkan para konsumen dapat menjawab semua masalah dengan innovasi yang bakal tercipta.

4. Perceived Popularity, adalah cerminan dari brand yang design oleh perusahaan untuk dapat di yakini oleh konsumen

\section{Perceived quality (X2)}

Perceived quality adalah standar kualitas yang nantinya akan di terima oleh konsumen. Indikator dari Perceived quality adalah:

1. Kinerja, Berhubungan dengan hasil kinerja yang di tunjukkan kepada konsumen

2. Pelayanan, Berhubungan dengan pelayanan yang diberikan perusahaan kepada konsumen

3. Ketahanan, Berhubungan dengan jangka waktu atau masa guna barang atau jasa yang di gunakan dalam masa waktu tertentu

4. Keandalan, Kemungkinan produk atau jasa untuk memenuhi kebutuhan atau keinginan pelanggan

5. Karakteristik Produk, Berhubungan dengan kepribadian atau visi misi perusahaan

6. Kesesuaian dengan Spesifikasi Kesesuaian dengan mutu produk yang dijanjikan oleh perusahaan kepada konsumen

7. Hasil, Berhubungan dengan manfaaat atau benefit yang diterima oleh konsumen

\section{Variabel Perantara $(\mathrm{Y})$}

\section{Brand Personalities (Y1)}

\section{Sincerity}

Karakter yang menunjukkan kualitas produk, dan identik dengan konsumen dari perusahaan

2. Excitement

Karakter yang mengembangkan semanagat ingin maju dan terus berinovasi

3. Competence.

Karakter yang berhubungan dengan kemudahan, keandalan dan kepercayaan konsumen. 


\section{Sophistication}

Karakteristik yang menunjukkan kebanggan yang mampu menjadi daya tarik perusahaan.

5. Ruggedness.

Karakteristik merek yang menunjang kegiatan di luar.

\section{Brand Trust (Y2)}

Kepercaayaan terhdapa mereka yang timbul dari upaya perushaan untuk memenuhi harapan dari konsumen:

\section{Fiablity}

Dimensi ini mewakili sebuah persepsi bahwa suatu merek dapat memenuhi dan memuaskan kebutuhan dan nilai konsumen

2. Intentionality

Dimensi ini mencerminkan perasaan aman dan terjamin bahwa merek tersebut akan bertanggung jawab dan peduli walaupun terjadi perubahanperubahan dimasa yang akan datang

Variabel Endogen (Z)

Customer Loyality (Z1)

1. Cogantive Loyality

Kesetiaan konsumen yang hanya terbatas pada manfaat dasar dari produk

2. Affective Loyality

Kesetiaan pelanggan karena menyukai manfaat dari merek perusahaan

3. Conative loyality

Kesetiaan konsumen dalam hal berjanji untuk akan melakukan pembelian ulang

4. Action Loyality

Kesetiaan konsumen dimana telah mencapai pembelian ulang

\section{Teknik Analisa Data}

Rata-rata Hitung adalah nilai yang diperoleh dengan cara menjumlahkan semua elemen dan membaginya dengan jumlah elemen (Malhotra, 2004, p.340). Dan penelitian ini menggunakan alat Smart $P L S$ untuk mengolah data tersebut. PLS sebagai model prediksi tidak mengasumsikan distribusi tertentu untuk mengestimasi parameter dan memprediksi hubungan kausalitas. Karena itu, teknik parametrik untuk menguji signifikasnsi parameter tidak diperlukan dan model untuk prediksi bersifat non-parametrik. Evaluasi model PLS dilakukan dengan mengevaluasi outer model dan inner model.Outer model merupakan model pengukuran untuk menilai validitas dan reliabilitas model. Melalui proses iterasi alogaritma, parameter model pengukuran (validitas konvergen, validitas diskriminan, composite reliabi- lity dan cronbranch's alpha) diperoleh, termasuk nilai R2 sebagai parameter ketetapan model prediksi.Inner model merupakan model struktural untuk memprediksi hubungan kausalitas antar variabel laten. Melalui proses bootstraping, parameter uji T-statistic diperoleh untuk memprediksi adanya hubungan kausalitas.

\section{ANALISA DAN PEMBAHASAN}

\section{Indicator Reliability}

Nilai indicator reliability didapatkan dari hasil pangkat dua dari outer loading tiap-tiap indikator yang digunakan. Nilai indicator reliability diatas 0,70 termasuk dalam kategori baik, 0,40 sampai 0,70 dianggap cukup, dan dibawah 0,40 dapat dikatakan tidak layak. Berikut merupakan nilai outer loading yang sudah diolah menjadi indicator reliability.

Variabel Brand Leadership memiliki indikator dengan tingkat reliabilitas cukup baik hingga baik. Keseluruhan indikator memiliki reliabilitas yang layak digunakan, sehingga dapat dijadikan bahan untuk mengolah data selanjutnya.

Variabel Perceived quality memiliki indikator dengan tingkat reliabilitas cukup baik hingga baik Keseluruhan indikator memiliki reliabilitas yang layak digunakan, sehingga dapat dijadikan bahan untuk mengolah data selanjutnya.

Variabel Brand Personality memiliki indikator dengan tingkat reliabilitas cukup baik. Namun pada indikator Y.1.14 memiliki nilai yang kurang baik. Hal ini menanyakan tentang setiap lulusan merlion dapat diterima di sekolah swasta melalui jalur prestasi. Hal ini kurang dapat diterima karena masih meungkinkan hasil penelitian ini tidak diterim melalui jalur prestasi, sehingga nilai indikator ini ditolak.

Variabel Brand Trust memiliki indikator dengan tingkat reliabilitas antara cukup baik hingga baik. Keseluruhan indikator memiliki reliabilitas yang layak digunakan, sehingga dapat dijadikan bahan untuk mengolah data selanjutnya.

Variabel customer loyalty juga memiliki keseluruhan indikator dengan tingkat reliabilitas yang cukup baik hingga baik. Sehingga peneliti dapat menggunakan variabel ini untuk tahap berikutnya.

\section{Uji Validitas}

Untuk memeriksa nilai convergent validity, diperlukan evaluasi Average Variance Extracted (AVE) setiap variabel laten. Nilai AVE harus lebih besar dari angka 0,5 untuk dapat memastikan bahwa tiap variabel memiliki rameter convergent validity yang layak digunakan. 
Tabel 1.

\begin{tabular}{lcc}
\hline \multicolumn{1}{c}{ Variabel } & AVE & Keterangan \\
\hline Brand Leadership & 0,65686 & Valid \\
Perceived Quality & 0,72005 & Valid \\
Brand Personality & 0,55692 & Valid \\
Brand Trust & 0,68680 & Valid \\
Customer Loyalty & 0,76156 & Valid \\
\hline
\end{tabular}

Menunjukkan bahwa keseluruhan variabel yang digunakan pada penelitian ini memiliki convergent validity yang layak. Dengan memastikan convergent validity, maka dapat dilanjutkan untuk pemeriksaan validitas tahap selanjutnya.

\section{Discriminant Validity}

Fornell dan Larcker (1981) menyarankan bahwa akar pangkat dua nilai AVE setiap latent variable harus lebih besar dari nilai korelasi terhadap variabel lainnya untuk memastikan discriminant validity.

\section{Fornell-Larcker Criterion Analysis for Checking Discriminant Validity}

Nilai $\mathrm{R}^{2}$ diatas 0,75 keatas dikategorikan substansial, $0,50-0,75$ artinya sedang, dan $0,25-0,50$ artinya lemah.

Angka yang bercetak tebal di Tabel 2. Didapatkan dari hasil akar pangkat dua nilai AVE pada latent variable, kemudian hasilnya dibandingkan dengan angka pada setiap latent variable lain yang berhubungan.

Tabel 2 .

\begin{tabular}{|c|c|c|c|c|c|}
\hline & $\begin{array}{l}\text { Brand } \\
\text { Leadership }\end{array}$ & $\begin{array}{l}\text { Perceived } \\
\text { Quality }\end{array}$ & $\begin{array}{l}\text { Brand } \\
\text { Personality }\end{array}$ & $\begin{array}{l}\text { Brand } \\
\text { Trust }\end{array}$ & $\begin{array}{l}\text { Customer } \\
\text { Loyalty }\end{array}$ \\
\hline $\begin{array}{l}\text { Brand } \\
\text { Leadership }\end{array}$ & 0,81047 & & & & \\
\hline $\begin{array}{l}\text { Perceived } \\
\text { Quality }\end{array}$ & 0,38879 & 0,84856 & & & \\
\hline $\begin{array}{l}\text { Brand } \\
\text { Personality }\end{array}$ & 0,43805 & 0,39244 & 0.74627 & & \\
\hline Brand Trust & 0,51051 & 0,40905 & 0.52288 & 0,82873 & \\
\hline $\begin{array}{l}\text { Customer } \\
\text { Loyalty }\end{array}$ & 0,24978 & 0,42189 & 0,27198 & 0,45488 & 0,87268 \\
\hline
\end{tabular}

Pada Tabel 2 dapat dijelaskan bahwa akar AVE Brand Leadership (0,81047) lebih besar dari korelasi Brand Leadership dengan Perceived Quality (0,38879), Brand Personality (0,43805), Brand Trust (0,51051), dan Customer Loyalty (0,24978). Sehingga variabel Brand Leadership dapat dikatakan valid.

Akar AVE variabel Perceived Quality $(\mathbf{0 , 8 4 8 5 6})$ juga lebih besar dari korelasi Perceived Quality dengan Brand Leadership (0,38879), Brand Persona- lity (0,39244), Brand Trust (0,40905), dan Customer Loyalty $(0,42189)$. Maka variabel perceived value dapat dikatakan valid.

Akar AVE variabel Brand Personality (0.74627) juga lebih besar dari korelasi Brand Personality dengan $e$ Brand Leadership (0,43805), Perceived Quality (0,39244), Brand Trust (0.52288), dan customer loyalty $(0,27198)$. Maka variabel brand image dapat dikatakan valid.

Akar AVE variabel Brand Trust (0,82873) juga lebih besar dari korelasi Brand Trust dengan $e$ Brand Leadership (0,51051), Perceived Quality $(0,40905)$, Brand Personality (0.52288), dan customer loyalty $(0,45488)$. Maka variabel brand image dapat dikatakan valid.

Kemudian, akar AVE variabel customer loyalty (0,87268) juga lebih besar dari korelasi customer loyalty dengan Brand Leadership (0,24978), Perceived Quality (0,42189), Brand Personality $(0,27198)$ dan Brand Trust $(0,45488)$. Dengan demikian, variabel customer loyalty dapat dikatakan valid.

Evaluasi Path Coefficient dan Coefficient of Determination $\left(R^{2}\right)$

Evaluasi path coefficient digunakan untuk menunjukkan seberapa kuat efek atau pengaruh variabel independen kepada variabel dependen. Sedangkan coefficient determination digunakan untuk mengukur seberapa banyak variabel endogen dipengaruhi oleh variabel lainnya. Didalam marketing research, nilai $\mathrm{R}^{2}$ diatas 0,75 keatas dikategorikan substansial, $0,50-$ 0,75 artinya sedang, dan $0,25-0,50$ artinya lemah.

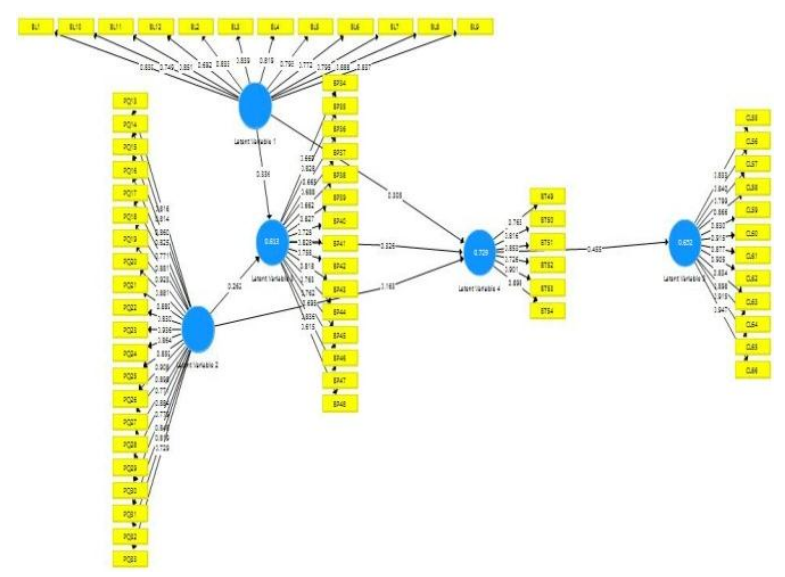

Gambar 3.

Pada analisa path coefficient ini telah dibuktikan bahwa Brand Leadership dan percieved quality memiliki pengaruh terhadap Brand Personality. Pengaruh Brand Leadership terhadap Brand Personality memiliki nilai pengaruh 0,334 dan nilai peng- 
aruh Perceived Quality terhadap Brand Personality memiliki nilai pengaruh 0,262 . Secara keseluruhan terdapat nilai positif pengaruh Brand Leadership dan percieved quality terhadap Brand Personality

Selain pengaruh Brand Leadership dan percieved quality terhadap Brand Personality, sebagai variabel perantara, Brand Leadership dan percieved quality juga memiliki pengaruh terhadap Brand Trust. Ditambah lagi nilai pengaruh Brand personality terdapat Brand Trust. Nilai pengaruh Brand Leadership terhdapa Brand Trust sebesar 0,305, sedangkan pengaruh Brand personality terhdapa Brand Trust memiliki nilai sebesar 0,326. Namun pengaruh percieved quality juga terhadap Brand Trust memiliki nilai pengaruh yang paling rendah. Yaitu 0,168 . Artinya, pengaruh Perceived Quality terhadap Brand Trust memiliki nilai yang rendah. Hal ini bisa di akibatkan karena Perceived Quality belum mampu membangun Brand Trust di Merlion School. Hal sangat mungkin terjadi pada perusahaan yang masih berusia muda. Merlion School yang baru berusia 8 tahun. Belum dapat menciptakan perceived quality yang kuat untuk membangun trust. Terlebih ini perusahaan jasa, sehingga lebih sulit membangun trust dibandingkan dengan perusahaan yang memproduksi produk, karena mereka dapat memeberika tester produk kepada konsumen.

Bila dibandingkan dengan keseluruhan masih di bawah nilai Brand Trust 0,455 yang berpengaruh langsung terhadap customer loyality. Ini membuktikan bahwa Merlion School mampu menjaga dan membangun Brand Trust mereka di benak konsumen, sehingga dapat membantu Brand Personality dan Perceived quality dalam meningkatkan customer loayalty dari konsumen mereka

Sementara itu, nilai coefficient of determination $\left(\mathrm{R}^{2}\right)$ yang pada gambar ditunjukkan pada angka di dalam lingkaran variabel nilai $\left(\mathrm{R}^{2}\right)$ dari Brand Personality adalah 0,613 artinya $61 \%$ nilai variable dipengaruhi oleh Brand Leadership dan Perceived Quality karena hasil dari penelitian terhadapat nilai Brand Personality yang cukup baik di dalam penelitian ini. Artinya Merlion School sudah mampu menerapkan Brand Personality yang baik di mata konsumen mereka.

Sama halnya dengan Brand Trust di benak konsumen, dengan nilai $\left(\mathbf{R}^{2}\right) 0,729$ artinya $73 \%$ dipengaruhi oleh Brand Leadership, Perceived Quality dan Brand Personality. Hal ini membuktikan bahwa nilai pengaruh dari ketiga variabel tersebut sangatlah kuat sehingga hanya $27 \%$ nilai dari Brand Trust yang diperngaruhi oleh variabel lainnya.

Pada analisis path coefficient ini Brand Trust menjadi variabel intervening yang tepat. Hal ini di- buktikan dengan nilai $\left(\mathrm{R}^{2}\right)$ Customer loyalty yang diperngaruhi oleh Brand Trust, terbukti nilai Customer Loyalty 65\% dipengaruhi oleh variabel Brand Trust ini membuktikan bahwa Brand trust adalah variabel yang tepat. Terlebih bagi perushaan jasa pendidikan, kepercayaan menjadi pegangan penting bagi konsumen untuk menentukan pilihan.

\section{T-statistics dan Uji Hipotesis}

Nilai T-statistics diperoleh dari prosedur bootstrapping, dimana nilai ini digunakan untuk menarik kesimpulan pada uji hipotesis. Nilai T-statistics dengan level signifikansi 5\% menjelaskan bahwa inner model akan signifikan jika nilai T-statistics lebih besar dari 1,96.

\section{T-statistics}

Berikut adalah hasil penarikan kesimpulan dari uji hipotesis.

Tabel 3.

\begin{tabular}{clc}
\hline Hipotesis & \multicolumn{1}{c}{ Keterangan } & T-statistics \\
\hline $\mathrm{H}_{1}$ & $\begin{array}{l}\text { Terdapat pengaruh signifikan dari } \\
\text { Brand Leadership terhadap Brand }\end{array}$ & 4.63488 \\
$\mathrm{H}_{2}$ & $\begin{array}{l}\text { Personality } \\
\text { Terdapat pengaruh signifikan dari } \\
\text { Brand Leadership terhadap Brand }\end{array}$ & 3.20501 \\
& $\begin{array}{l}\text { Trust } \\
\mathrm{H}_{3}\end{array}$ & $\begin{array}{l}\text { Terdapat pengaruh signifikan dari } \\
\text { Perceived Quality terhadap Brand }\end{array}$ \\
$\mathrm{H}_{4}$ & $\begin{array}{l}\text { Personality } \\
\text { Terdapat pengaruh signifikan dari }\end{array}$ & 1.55689 \\
& $\begin{array}{l}\text { Perceived Quality terhadap Brand } \\
\text { Trust } \\
\mathrm{H}_{5}\end{array}$ & $\begin{array}{l}\text { Terdapat pengaruh signifikan dari } \\
\text { Brand Personality terhadap } \\
\text { Brand Trust }\end{array}$ \\
$\mathrm{H}_{6}$ & $\begin{array}{l}\text { Terdapat pengaruh signifikan dari } \\
\text { Brand Trust terhadap Customer } \\
\text { Loyality }\end{array}$ & 6.15151 \\
\hline
\end{tabular}

Brand Leadership terhadap Brand Personality

Brand Leadership adalah upaya yang dilakukan oleh perusahaan untuk menciptakan kekuatan pada merek Merlion School, dimana Brand Leadership menjadi kekuatan utama bagi Merlion School. Kekuatan ini tercipta dari kerjasama antara merlion School dengan NIE dimana Merlion School berhak mengadakan iPSLE yang diakui di luar negeri.

Dimana melalui Brand Leadership yang dilakukan Merlion School. Mengajarkan budi pekerti, mengajarkan agama, nilai, norma dan etika yang di masukkan dalam kurikulum kegiatan belajar mengajar. Merlion School tidak hanya mencetak lulusan yang pandai namun juga memiliki karakter yang baik. 
Tabel 4

\begin{tabular}{|c|c|c|c|c|c|}
\hline & $\begin{array}{l}\text { Original } \\
\text { Sample } \\
\text { (O) }\end{array}$ & $\begin{array}{l}\text { Sample } \\
\text { Mean } \\
\text { (M) }\end{array}$ & $\begin{array}{l}\text { Standard } \\
\text { Error } \\
\text { (STDERR) }\end{array}$ & $\begin{array}{l}\text { Standard } \\
\text { Deviation } \\
\text { (STDEV) }\end{array}$ & $\begin{array}{c}\text { T Statistics } \\
\text { (|O/STERR|) }\end{array}$ \\
\hline $\begin{array}{l}\text { Brand } \\
\text { Leadership } \\
\rightarrow \text { Brand } \\
\text { Personality }\end{array}$ & 0.33631 & 0.35078 & 0.07256 & 0.07256 & 4.63488 \\
\hline $\begin{array}{l}\text { Brand } \\
\text { Leadership } \\
\rightarrow \text { Brand } \\
\text { Trust }\end{array}$ & 0.30458 & 0.30741 & 0.09503 & 0.09503 & 3.20501 \\
\hline $\begin{array}{l}\text { Perceived } \\
\text { Quality } \\
\vec{\rightarrow} \text { Brand } \\
\text { Personality }\end{array}$ & 0.26169 & 0.26055 & 0.07357 & 0.07357 & 3.55689 \\
\hline $\begin{array}{l}\text { Perceived } \\
\text { Quality } \\
\rightarrow \text { Brand } \\
\text { Trust }\end{array}$ & 0.16287 & 0.17004 & 0.09891 & 0.09891 & 1.64662 \\
\hline $\begin{array}{l}\text { Brand } \\
\text { Personality } \\
\rightarrow \text { Brand } \\
\text { Trust }\end{array}$ & 0.32554 & 0.32231 & 0.10330 & 0.10330 & 3.15151 \\
\hline $\begin{array}{l}\text { Brand Trust } \\
\rightarrow \text { Customer } \\
\text { Loyalty }\end{array}$ & 0.45488 & 0.46872 & 0.07159 & 0.07159 & 6.35376 \\
\hline
\end{tabular}

\section{Brand Leadership terhadap Brand Trust}

Kepercayaan merek terbentuk ketika sebuah merek mampu memenuhi kebutuhan dan juga mampu memberikan manfaat secara nyata dan menjalin hubungan emosional dengan konsumen, sehingga terbentuklah kepercayaan konsumen dari hal-hal yang diberikan oleh perusahaan.

Penelitian ini membuktikan melalui dimensidimensi yang terdapat pada Brand Leadership seperti Merlion School mampu membuktikan keunggulannya dalam segi networking mereka, dan bandingkan dengan pesaing. yang berdampak pada kepercayaan terhadap merek, dari segi networking mereka mendapat pengakuan dari Cambrige University, lalu Sertifikat S-IPSLE (Singapore Internasional Primary School Examination), dan NIE. Yang dimana merupakan lembaga-lembaga pendidikan yang dapat dipercaya

\section{Perceived Quality dengan Brand Personality}

Dari persepsi kualitas, konsumen mampu menggambarkan atau menilai kualitas yang di dapatkan dari Merlion School.

Hal ini dibuktikan dengan pengaruh perceived quality terhadap Brand Personality juga berpengaruh signifikan dengan nilai uji T-statistics > 1,96 yaitu 3.55689. Hal ini dibuktikan dengan hasil yang kita peroleh dari belajar di Merlion School.
Persepsi Kualitas di tunjukan melalui FasilitasFasilitas yang dimiliki kemudian, lalu metode pengajaran yang digunakan memiliki standar Internasional. Hal ini membentuk Brand Personality dari merek Merlion Sebagai Sekolah Internasional yang Berkulitas.

\section{Perceived Quality terhadap Brand Trust}

Persepsi Kualitas yang dimiliki oleh Merlion School belum mampu berpengaruh signifikan terhadap Brand Trust. Hal ini dibuktikan dengan nilai uji T-statistics $<1,96$ dengan nilai 1.64662. ini membuktikan bahwa Perceived Quality belum mampu mempengaruhi kepercayaan konsumen secara signifikan, hal ini dikarenakan Perceived Quality pada Merlion School belum mampu memberikan pelayanan yang optimal. Dimana bagi perusahaan jasa, pelayanan adalah hal yang utama.

Konsumen saat ini percaya bahwa merlion memiliki produk yang berkualitas. Namun dalam segi pelayanan. Merlion School tidak memberikan pelayanan yang optimal, sehingga kepercayaan konsumen pada merlion School juga tidak optimal.

\section{Brand Personality terhadap Brand Trust}

Brand Personality adalah gambaran merek yang ada di benak konsumen. Hal ini menunjukkan bahwa ada pengaruh signifikan antara Brand Personality terhadap Brand trust dengan nilai uji T-statistics > 1,96 yaitu 3.15151. Artinya bahwa personalitas yang dimiliki oleh Merlion School sudah mampu membuat konsumen percaya.

Kepercayaan ini muncul karena nilai $\mathrm{RICCH}$ yang dibawa oleh merlion School menjadi keunggulan yang dimiliki Merlion School. Konsumen percaya bawah RICCH selalu muncul dalam seluruh hasil dari merlion yang ada di dalam diri guru, murid dan orang tua, melalui kegiatan yang mendukung perkembangan para siswanya, terbentuklah saling percaya Tentunya hal ini juga di dukung dengan metode pengajaran yang baik, serta hasil yang diharapakan oleh konsumen dapat dipenuhi oleh Merlion School.

\section{Brand Trust terhadap Customer Loyalty}

Pada penelitian ini, hubungan variable di ataslah yang tidak memiliki nilai pengaurh signifikan dimana Brand trust terhadap customer loyalty. Pada hasil penelitian ini diketahui bahwa adanya pengaruh secara signifikan tersebut merupakan hasil uji Tstatistik dengan nilai uji T-statistics > 1,96 yaitu 6.35376, 
Pada penelitian ini Kepercayaan terbentuk dari adanya harapan dari konsumen yang mampu dipenuhi oleh Merlion School, serta terjalin hubungan emosional antara merlion dengan konsumen terbukti dari fasilitas - fasilitas yang dimiliki oleh Merlion School mampu, metode pengajaran, dan pelayanan dari Merlion School membuat konsumen mereka percaya akan hasil dan kualitas dari Merlion School, yang menjadikan konsumen mereka loyal.

\section{KESIMPULAN DAN SARAN}

Berdasarkan hasil penelitian diperoleh hasil sebagai berikut: Berdasarkan hasil penelitian mengenai analisa Pengaruh Brand Leadership dan Perceived Quality terhadap Customer Loyalty dengan Brand Personality Sebagai variabel perantara serta Brand Trust sebagai variabel intervening di Merlion School Surabaya maka diperoleh hasil sebagai berikut:

- Brand Leadership. Pada dasarnya Brand Leadership adalah kekuatan utama yang dibentuk Merlion School sebagai kekuatan yang dimiliki oleh Merlion School. Hal ini diciptakan untuk membentuk percepsi konsumen terhadap kekuatan yang dimiliki oleh Merlion School tentang keunggulan yang dimiliki oleh Merlion School yang membentuk Brand Personality dari Merlion School. Hal ini terbentuk dari adanya Networking yang terbangun sesuai dengan indicator X.1.8. Kerjasama antara Merlion School dengan NIE dan Cambrige yang mampu menciptakan produk inovasi yang berkualitas melalui kurikulum yang menggabungkan antara pendidikan akademis dan pendidikan karakter yang membuktikan keberhasilan Brand Leadership dalam mencetak lulusan yang pandai dan berkarakter baik.

- Brand Leadership, berpengaruh signifikan terhadap Brand Trust. Hal ini dimunculkan dari adanya keunggulan dalam persepsi yang timbul dari apa yang diciptakan Merlion School untuk konsumen. Dibuktikan dengan adanya keunggulan yang diberikan oleh Merlion School Mampu membentuk persepsi konsumen akan kemampuan Merlion dalam menjawab kebutuhan konsumen dalam hal ini Guru yang berkulitas, mendapat pengakuan NIE, Siswa merlion memenangi lomba SASMO. X2.3 Hal ini menimbulkan kepercayaan yang muncul ketika Merlion School mampu memenuhi kebetulan dan dapat menjalin hubungan emosional dengan konsumen.

- Persepsi kualitas adalah persepsi konsumen tentang kualitas yang dimiliki oleh Merlion School, sehingga dari persepsi kualitas yang dimiliki oleh
Merlion School, Konsumen menilai tentang kualitas yang ditimbulkan dari produk, fasilitas dan pelayanan, yang membentuk personality dari Merlion School. Perceived quality menjadi sangat penting dalam membentuk persepsi konsumen tertang brand personality yang dimiliki oleh Merlion School yang menjadi keunggulan Merlion School di bandingkan dengan pesaing.

- Perceived quality memiliki pengaruh tidak signifikan terhadap brand trust. Perceived Quality gagal membangun kepercayaan merek Merlion School di persepsi konsumen. Ini diakibatkan karena Merlion School hanya memberikan pelayanan yang standart, sehingga tidak terjalin hubungan yang kuat antara konsumen dengan brand karena tidak adanya kontak langsung anatara guru Merlion School dengan konsumen, dimana pelayanan adalah hal yang paling utama bagi sebuah perusahan.

- Brand Personality adalah karakter yang dimiliki oleh perusahaan. Persepi kualitas yang dimiliki oleh Merlion School, serta Brand leadership yang dibentuk oleh perushaan menciptakan keunggulan di dalam Merlion School. Hal ini dibuktikan dengan Brand Personality yang dimiliki Merlion School yaitu RICCH, berushaan untuk ditanamkan pada setiap produk yang dihasilkan oleh Merlion School yaitu para siswa Merlion School, guru, sistem, para pimpinan, dan orang tau murid.

- Brand trust memiliki pengaruh terhadap customer loyality. Penting bagi sebuah perusahaan jasa pendidikan membangun kepercayaan di benak konsumen, hal ini dikarenakan tanpa adanya kepercayaan yang kuat atas brand tersebut. Sangat sulit bagi Merlion School untuk mempertahankan konsumennya. Ini mengapa customer loyalty menjadi penting untuk membangun sebuah perusahaan yang berkelanjutan.

Dari seluruh kesimpulan diatas, menunjukan bahwa Merlion School, sebagai sebuah sekolah internasional membutuhkan kepercayaan konsumen dan memperoleh konsumen yang loyal. Hal ini di buktikan dengan Brand Leadership yang diciptakan oleh Merlion School menjadi sebuah keunggulan yang dimilki, dan juga perceived quality menjdai persepsi kualitas konsumen tentang Merlion School. Hal ini didukung dengan pembentukkan Brand Personality sebagai keunggulan yang nyata melalui RICCH.

\section{Saran}

Merujuk kepada hasil penelitian dan pembahasan, berikut ini peneliti mengajukan beberapa saran khususnya untuk Merlion School Surabaya: 
- Meningkatkan Brand Leadership Merlion School hal ini digunakan untuk meningkatkan keunggulan yang dimiliki oleh Merlion School, sehingga menimbulkan keunggulan di seluruh bagian di Merlion School.

- Meningkatkan perceived quality pada benak konsumen dengan terus meningkatkan kualitas, terutama kualitas pelayanan. Selama ini merlion belum fokus pada pelayanan. Mereka masih terfokus pada pembentukan proddk dan sistem pendidikan. Hal ini tidak berdampak signifikan terhadap kepercayaan konsumen.

- Meningkatkan Brand Personality, Brand Peronality diciptakan untuk menjadi keunggulan bagi Merlion School dibandingkan dengan pesaingpesiang mereka. Keunggulan itu harus mampu diciptakan dari segala aspek, baik dari segi produk, layanan, dan juga keberhasilan dari siswasiswinya.

- Meningkatkan Customer loyalist. inilah yang menjadi tujuan utama dari seluruh perusahaan mendapatkan konsumen yang loyal, dengan mendorong konsumen loyal hingga pada tingkat repeat purchase.

- Implementasi dengan menerapkan value RICCH yang terintegrasi pada Merlion School. Yaitu metode pengajaran, sistem pengajaran, nilai yang dibawa oleh seluruh guru-guru, dan juga ditekankan pada para siswa.

\section{DAFTAR PUSTAKA}

Aaker, David A. (1991). Managing brand Aaker, D.A. 1996, Building Strong Brands, The Free Press, New York, NY.

Business News. (2013). Summary: Brand-Leadership David Aaker and Erich Joachimsthaler. Primento.

Chang, Y. \& Ko, Y.J. (2014). The brand leadership: Scale development and validation. Journal of Brand Management, 21(1), 63-80.
Durianto, Sugiarto dan Tony Sitinjak. (2001). Strategi Menaklukkan Pasar Melalui Riset Ekuitas dan Perilaku Merek. PT. Gramedia Pustaka Utama, Jakarta.

Fornell, C. \& Larcker, D.F. (1981). Evaluating structural equation models with unobservable variables and measurement error. Journal of Marketing Research, 18(1), 39-50.

Gavin, David A. (1987). Managing Quality, New York USA: The Free Press.

Griffin, Jill. (2005). Customer Loyalty: Menumbuhkan dan Mempertahankan Kesetiaan Pelanggan. Alih Bahasa: Dwi Kartini Yahya. Jakarta: Erlangga

Hellier, P. K., Ceursen, G. M., Carr, R. A., \& Rickard, A. (2003). Customer repurchase intention: A general structural equation model. European Journal of Marketing, 37(11/12).

http://profilsekolah.dispendik.surabaya.go.id/umum/r eport.php. accesed: 28 Mei 2014

Kustini dan, Ika, Nuruni. 2011. Experiental Marketing, Emotional Branding, and Brand Trust and their Effect on Loyalty on Honda Motorcycle Product. Journal of Economics, Business, and Accountancy Ventura, 14(1), April 2011, pp. 1928.

Kotler, Philip dan Gary Armstrong. (2004). Dasardasar pemasaran, terjemahan Alexander Sindoro, Edisi 9, Jilid 1, Indeks. Jakarta.

[Kotler, P. and Keller, K. (2006): Marketing Management, $12^{\text {th }}$ ed, Prentice Hall.

Lau, Geok Theng dan Sook Han Lee. 1999. Consumer Trust in a Brand and the Link to Brand Loyalty. Journal of Market Focused Management, Vol. 4.

Malhotra, N.K., (2004) Marketing Research: An Applied Orientation. New Jersey: Pearson Education Inc.

Oliver, R.L. (1999). Whence Consumer Loyalty, Journal of Marketing, 63(Special Issue): 33-44. 